\title{
DigitÁlis KOMPETENCIA A FELSŐFOKÚ VÉGZETTSÉGÜEK KÖRÉBEN
}

\author{
CZEGLÉDI CSILLA ${ }^{\mathrm{a}}$ - JUHÁSZ TÍMEA ${ }^{\mathrm{b}, *}$ \\ ${ }^{a}$ ELTE PPK Felnőttképzés-kutatási és Tudásmenedzsment Intézet

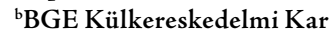

Napjainkban a munkaerőpiac egyre magasabb szintű digitális kompetenciával rendelkező munkavállalókat igényel. A piac igényei konkrétak, de kérdés, hogy a leendő munkavállalók vagy a munkaerőpiacon már aktívan jelen lévők mennyiben tudják teljesíteni ezt a követelményt. A felsőfokú végzettséggel rendelkezők körében 2019-ben felvett online kérdőíves felmérésünkben arra kerestük a választ, hogy a válaszadók munkahelyükön és otthon miként használják a kor digitális eszközeit, és miként értékelik a saját digitális kompetenciájukat. Az eredmények azt mutatták, hogy a diplomások magas szintü digitális kompetenciával rendelkeznek és képesek ezeket az ismereteket otthon és a munkahelyen is alkalmazni.

Kulcsszavak‡ generáció, infokommunikáció, digitális eszközök

Nowadays one of the most important aspects of meeting the needs of the labour market today is that employees have what kind of digital competence. Employers often expect that the employees have high level of knowledge in this direction. The needs of the market are concrete, but it is a question of how well applicants or those already active in the labour market can meet this requirement. This year, the authors conducted a comprehensive online survey of graduate students on how respondents use digital tools of the age both at work and at home, and how they evaluate their own knowledge in the field at all. The results showed that graduates have a high level of digital competence and are able to apply this knowledge at home and at work.

Keywords: generation, info communication, digital devices

\footnotetext{
Levelező szerző: Dr. habil Juhász Tímea, BGE Külkereskedelmi Kar, 1165 Budapest, Diósy Lajos u. 22-24.

E-mail: juhasz.timi@hotmail.com
} 


\section{Digitális kompetencia}

A digitális kompetencia meghatározására az egyik legelterjedtebb az Európai Bizottság által kidolgozott Európai Digitális Kompetencia Keretrendszerben (DigComp 2.1.) alkalmazott megközelítés, amely öt szinten azonosítja a kompetenciákat: 1) információ- és adatmenedzsment, 2) kommunikáció és együttmüködés, 3) digitális tartalmak, 4) biztonsággal kapcsolatos ismeretek, 5) digitális eszközök önálló, rutinszerű kezelése, technikai problémák megoldása (Carretero-VuorikariPunie, 2017). A jelenleg még hatályban lévő 2012. évi Nemzeti alaptantervben a digitális kompetencia a nyolc kulcskompetencia egyike, amely felöleli az infokommunikációs technológiák (IKT) és az azok által hozzáférhetővé tett, közvetített tartalmak magabiztos, kritikus és etikus használatát a társas kapcsolatok, a munka, a kommunikáció és a szabadidő terén (NAT 2012).

Az ipari társadalmat fokozatosan felváltotta az információs, majd a tudásalapú társadalom, amely teljesen átírta az emberek közötti kommunikáció rendjét. Az internet megkönnyíti az információk megszerzését, ugyanakkor megváltoztatja az emberek közötti kapcsolatok személyes jellegét. A 21. században a digitális kompetencia az infokommunikációs technológiákhoz való hozzáférést és azok használatát jelenti, továbbá magában foglalja a kapcsolódó ismeretek, a készségek és az attitüdök megfelelő szintű birtoklását is. A digitalizáció fejlődése fontos hatást gyakorol a munkaerőpiacra is. A munkáltatók jogos elvárása, hogy a dolgozók biztosan használják, kezeljék a digitális eszközöket és alkalmazásokat. A munkavállalói oldalon pedig a korábbinál nagyobb mennyiségű információ, eszköz jelenik meg az álláskeresés és a munkában való helytállás valamennyi fázisában.

A digitális gazdaság és társadalom fejlettségi szintjét mérő uniós DESI index ${ }^{1}$ azt jelzi, hogy hazánk a „lemaradók” csoportjába tartozik: Magyarország a 23. helyen áll a 28 uniós tagországot rangsoroló listán. Az index egyrészt alacsonyabb értékü, mint az európai uniós átlag, és emellett a fejlődés üteme is elmarad az Európai Unió átlagos növekedési ütemétől (Európai Bizottság, 2019). A lakosság digitális kompetenciáinak fejlesztése a magyar nemzetgazdaság növekedésének és versenyképességének fontos tényezője. A magyar munkavállalók foglalkoztathatósága, munkaerőpiaci esélyei jórészt azon múlnak, hogy meg tudnak-e felelni a digitális kor elvárásainak, függetlenül attól, hogy milyen szakmában és milyen beosztásban dolgoznak.

Székely és Aczél (2018) szerint a médiatartalmak számának növekedése, elérhetősége az infokommunikációs technológia rohamos fejlődésével karöltve megváltoztatta a társadalom és az egyén életét egyaránt. Ez a fejlődés hatást gyakorol a társas kapcsolatokra, a tudás megszerzésére, befolyással bír a munka világára és az ipar fejlődésére. Egyszóval globális jelenség és nem csupán földrajzilag, hanem az ember életét átszövő valamenynyi szegmens vonatkozásában. Az internet levált eredeti hordozójáról, a számítógépről, a fiatalok otthonában egyre több olyan IKT-eszköz található meg, amelyek alkalmasak az internet nyújtotta szolgáltatások használatára. A behuzalozottság és a konnektáltság

DESI Index (Digital Economy and Society Index) dimenziói: internet-hozzáférés, humán tőke (digitális készségek), internetes szolgáltatások használata, digitális technológiák integráltsága és digitális közszolgáltatások. 
többféle eszközön valósul meg: tablet, okostelefon, okosóra, netbook, amelyekkel egyidejüleg a televízió, a rádió, az újság háttérbe szorulása figyelhető meg. A szabadidő eltöltésének kétharmadában a digitális média van jelen. Vagyis a magyar fiatalok médiafogyasztásuk tekintetében hasonló képet mutatnak, mint nyugati kortársaik: a hagyományos elektronikus média és a nyomtatott sajtó veszített a népszerüségéből, helyüket az internet nyújtotta médiafogyasztás vette át. Az okostelefonok elterjedésével pedig visszaszorult azoknak az eszközöknek a használata is, amelyek helyhez kötöttek, úgymint a televízió vagy az asztali számítógép.

\section{A kutatás módszertana}

A kutatások alapján (lásd például Európai Bizottság 2019) a magyar társadalom digitális kompetenciája fejleszthető, erősíthető. Természetesen nem az összes társadalmi csoportra igaz, hogy messze az uniós átlag alatt vannak az ez irányú kompetenciáik. A kutatás egy speciális csoport, a diplomával rendelkezők digitális kompetenciáit vizsgálta, abból kiindulva, hogy már a végzettség megszerzéséhez és különösen utána, a munkahelyen elvárás ennek a kompetenciának a magas szintủ alkalmazása.

A felsőfokú végzettségűek digitális kompetenciájára vonatkozó online kérdőíves adatfelvételre 2019-ben került sor. A válaszadók a kérdőívet interneten keresztül tudták kitölteni, a minta kialakítása pedig hólabda módszerrel történt, így a minta nem tekinthető reprezentatívnak. Ez azt is jelenti, hogy eredményeink nem általánosíthatók, kizárólag a mintában szereplő válaszadókra érvényesek. Ugyanakkor az álláspontunk szerint a válaszokból levonható következtetések alapot adhatnak olyan kutatási irányoknak, amelyeket érdemes lenne további vizsgálatok fókuszába tenni. A kérdőív zárt kérdéseket tartalmazott, továbbá nominális és metrikus skálákra épült. A kérdőív kérdései több területre fókuszáltak: a minta specifikálása (háttérváltozók), a digitális jártasság, a digitális tudás a munkaerőpiacon (1. táblázat).

1. táblázat: A kérdőív tartalma

\begin{tabular}{lcc}
\hline \multicolumn{1}{c}{$\begin{array}{c}\text { A minta specifikálása } \\
\text { (háttérváltozók) }\end{array}$} & Digitális jártasság & $\begin{array}{c}\text { Digitális tudás a munkaerő- } \\
\text { piacon }\end{array}$ \\
\hline - Nem & - Digitális készségek és & - Munkaerőpiaci elvárások a \\
- Életkor & képességek otthon & digitális tudással szemben \\
- Munkaerőpiaci státusza & - Digitális készségek és & - Digitális tudás az egyén és a \\
& képességek a munkahelyen & munkaerőpiac szükségleteiben \\
\hline
\end{tabular}

Forrás: Saját szerkesztés

A kutatásban 193 felsőfokú végzettséggel rendelkező válaszadó vett részt. Az eredmények kiértékelése egy- és többváltozós statisztikai módszerekkel, így gyakoriság-, szórás- és átlagvizsgálattal, ANOVA elemzéssel, faktoranalízissel és korrelációelemzéssel történt. A kutatás során számos hipotézist vizsgáltunk, melyek közül jelen tanulmány a következöre fókuszál: A vizsgálatban részt vevö felsöfokú végzettségüek digitális kompetenciája általában fejlett, és mind a munkahelyükön, mind otthon rendszeresen használják ezt a tudást. 


\section{A minta jellemzése}

A válaszadók között többségben voltak a nők (123 fö), mint a férfiak (70 fó). Lakóhelyüket vizsgálva 65\%-uk budapesti volt, 11,4\%-uk közép-magyarországi, míg legkisebb arányban (2,1\%) az Észak-Alföldről érkeztek válaszok.

A minta átlagos életkora 35,4 év volt, tehát a minta nagyobb arányban a $Z$ és $Y$ generációból került ki, akikről tudjuk, hogy hozzájuk a digitalizáció közel áll. Az ehhez a generációkhoz tartozók esetében az internet és a különböző elektronikus eszközök ismerete és használata teljesen természetes, az idejük nagy részét a világhálón töltik, virtuális közösségekben élik életüket. Az Y és a Z generáció a digitalizáción szocializálódott első generációk, és a korábbi kutatások azt mutatják (Tari 2010), hogy innovatívak és napi szinten használják a technikai eszközöket.

A munkaerőpiaci státuszukat vizsgálva a kutatásban részt vevők $54 \%$-a szellemi foglalkozású volt, mintegy 35\%-a vezető, a többiek inaktívak (tanulók, GYED-en, GYESen lévők) voltak a munkaerőpiacon.

\section{A kutatás eredményei}

A kérdőív rákérdezett a résztvevők digitális képességeire és készségeire. A válaszadóknak egy ötfokozatú skálán - ahol az 1-es igen gyenge, az 5-ös nagyon erös értékelést jelentett - kellett önmagukat értékelniük, megadott szempontok alapján. A 2. táblázat adataiból kiolvasható, hogy a megkérdezettek alapvetően jónak értékelik a digitális ismereteiket, és e tekintetben igen homogén a minta. A válaszadók nem zárkóznak el az új dolgoktól, igen pozitívan viszonyulnak az újdonságokhoz. Otthon kevésbé, mint inkább a munkahelyükön alkalmazzák az ez irányú tudásukat.

2. táblázat: A válaszadók digitális kompetenciája

\begin{tabular}{lll}
\hline Ön milyennek értékeli... & Átlag & Szórás \\
\hline a digitális tudásának kihasználtságát a munkahelyén? & 3,87 & 0,835 \\
a digitális ismereteit? & 3,85 & 0,721 \\
a digitális innovációk iránti elfogadottságát? & 3,80 & 0,881 \\
a digitális újdonságok iránti érdeklődését? & 3,69 & 0,899 \\
a digitális újdonságokkal szembeni pozitív előítéleteit? & 3,63 & 0,869 \\
a digitális tudásának kihasználtságát otthon? & 3,47 & 0,936 \\
a digitális újdonságokkal szembeni negatív előítéleteit? & 2,74 & 1,175 \\
\hline
\end{tabular}

Forrás: Saját szerkesztés

Az adott változókból egy főkomponenst képeztünk, amelynek a magyarázott hányada 49,2\% volt. A 3. táblázat jól mutatja, hogy a fókomponensen igen nagy a faktorsúlya a digitális ismeretnek, a digitális innovációk iránti elfogadottságnak, az újdonság iránti érdeklődésnek és a tudás otthoni kihasználtságának. A kapott főkomponens tehát úgy értelmezhető, hogy minél magasabb az értéke, annál erősebbnek mondható a válaszadó digitális kompetenciája. 
3. táblázat: A főkomponens faktorsúlyai

\begin{tabular}{lc}
\hline Ön milyennek értékeli & Faktorsúly \\
\hline a digitális ismereteit? & 0,826 \\
a digitális innovációk iránti elfogadottságát? & 0,812 \\
a digitális újdonságok iránti érdeklődését? & 0,760 \\
a digitális tudásának kihasználtságát otthon? & 0,756 \\
a digitális tudásának kihasználtságát a munkahelyén? & 0,683 \\
a digitális újdonságokkal szembeni pozitív előítéleteit? & 0,629 \\
a digitális újdonságokkal szembeni negatív előítéleteit? & 0,302 \\
\hline
\end{tabular}

Forrás: Saját szerkesztés

Elemzésünkben megvizsgáltuk, hogy nemek szerint lehet-e különbséget tenni a fökomponens alapján. Az ANOVA elemezés nem mutatott szignifikáns különbséget: $F=0,707$; df: 160 ; szign.: 0,915; $p>0,05$. A kor alapján négy generáció különböztethető meg a mintában: a baby boom (1940-1959), az X (1960-1983), az Y (1984-1994), és a Z (1995-2009). Az ANOVA elemzés szignifikáns különbséget mutatott a négy korcsoport között: $F=15,104$; df 3; szign.: 0,001; $p<0,05$. Legerősebb digitális kompetenciái a $Z$ és az Y generációnak voltak. Megvizsgáltuk azt is, hogy a munkaerőpiaci státusz szerint tapasztalható-e különbség. Az ANOVA eredmények alapján nem mutatható ki különbség a vezetők és a beosztottak között $(F=2,327$; df: 3 ; szign.: 0,1; $p>0,05)$.

A digitális képességek felmérése után érdemesnek tartottuk megvizsgálni, hogy a válaszadók által birtokolt kompetencia miben segítheti őket. Ennek megválaszolásához több lehetőségröl kellett a megkérdezetteknek eldönteniük, hogy az adott területen ez a képesség támogatja-e őket, avagy sem. Leginkább az operatív feladatok teljesítésében könnyíti meg a válaszadók életét, ha erős digitális képességekkel rendelkeznek. Ez megmutatkozik abban is, hogy ki, milyen karriert tudhat majd magának, illetve hogy mennyire tudja hasznosan a munkaidejét beosztani (4. táblázat). Vagyis ezek az eszközök nemcsak otthon, de a munkahelyen is a hatékonyabb és a kényelmes munkavégzést hivatottak ellátni és szolgálni. Az előzőekben létrehozott, a válaszadók digitális kompetenciáját mérö fökomponens alapján ANOVA vizsgálattal bizonyítható volt, hogy a válaszadók digitális kompetenciája között szignifikáns különbség tapasztalható a munka betanításában, a munkaidő csökkentésében, az előbbre jutási lehetőségekben, a kapcsolatok kiépítésében. Az elemzések azt is igazolták, hogy ezekben az esetekben nagyobbak azoknak a lehetőségeik, akik erős ilyen tudással rendelkeznek, mint azoknak, akik gyengébbekkel. Nemek szerint az előbbre jutási lehetőségben van különbség (nőknek jobban segít), míg a pozíciók tekintetében az utazási lehetőségben, a szervezeti kultúrában történő beilleszkedésben, illetve a mentor biztosításában (elsősorban a vezetőket támogatja).

Felvetődik a kérdés, hogy ez a digitális tudás miképpen vált a válaszadók hasznos ismeretévé, azaz, hogy hol és miképpen sajátították el ezt a jártasságot. A lehetséges formák gyakoriságát egy ötfokozatú skálán - ahol 1-es az egyáltalán nem gyakori, az 5-ös az igen gyakori választ jelentette - kellett meghatározniuk a megkérdezetteknek. A formális iskolai, valamint a nem formális iskolai- és önképzés a leggyakoribb olyan lehetőség, 
CZEGLÉdI CSILLA - JUHÁSZ TÍMEA: DIGITÁLIS KOMPETENCIA...

4. táblázat: A válaszadók digitális kompetenciájának felhasználási lehetőségei (\%)

\begin{tabular}{lccc}
\hline Lehetőségek & Igen & Nem & Összesen \\
\hline Munka betanításában & 93,8 & 6,2 & 100,0 \\
Képzési lehetőségben & 91,2 & 8,8 & 100,0 \\
Kapcsolatok kiépítésében & 90,2 & 9,8 & 100,0 \\
Munka minőségi tartalmában & 87,0 & 13,0 & 100,0 \\
Előbbre jutási lehetőségben & 82,9 & 17,1 & 100,0 \\
Munkaidő csökkentésében & 80,3 & 19,7 & 100,0 \\
Utazási lehetőségben & 69,9 & 30,1 & 100,0 \\
Részvétel a munkáját érintő döntésekben & 68,4 & 31,6 & 100,0 \\
Szervezeti kultúrába történő beilleszkedésben & 66,8 & 33,2 & 100,0 \\
A cég szociális eseményeiben történő részvételben & 63,7 & 36,3 & 100,0 \\
Érdekérvényesítésben & 59,6 & 40,4 & 100,0 \\
Mentor biztosításában & 58,0 & 42,0 & 100,0 \\
Béren kívüli juttatásban & 51,3 & 48,7 & 100,0 \\
\hline
\end{tabular}

Forrás: Saját szerkesztés

amely során a digitális tudás birtokába jutnak a válaszadók. Érdekes, hogy a családon belüli, illetve a generációk közötti képzés valószínűsége alacsony. Azonban azt is látni kell, hogy minden elsajátítási lehetőség esetében magasak voltak a szórásértékek, azaz a válaszadók nem gondolkodtak egyöntetüen e tekintetben.

5. táblázat: A digitális kompetencia elsajátításának lehetőséges módjai a válaszadók körében (ötfokozatú skála átlaga, szórása)

\begin{tabular}{lll}
\hline Elsajátítási lehetőségek & Átlag & Szórás \\
\hline Iskolai (formális) keretek között & 3,36 & 1,322 \\
Iskolai és önképzés (nem formális) keretek között & 3,34 & 1,344 \\
Teljesen önképzés keretében & 3,29 & 1,363 \\
Munkahelyi kollegiális betanítás & 3,09 & 1,267 \\
Munkahelyi formális képzés & 2,99 & 1,356 \\
Ismerősök, barátok segítenek otthon & 2,73 & 1,395 \\
Iskolán kívüli felnőttképzés (formális) keretében & 2,46 & 1,453 \\
Közvetlen hozzátartozó oktat otthon & 2,46 & 1,425 \\
Iskolán kívüli felnőttképzés (e-learning) keretében & 2,25 & 1,373 \\
\hline
\end{tabular}

Forrás: Saját szerkesztés

Az ANOVA elemzés alapján elmondható, hogy a nők és a férfiak a következő elsajátítási formákat tekintve mutattak szignifikáns különbségeket: az iskolán kívüli felnőttképzés (e-learning keretekben), a teljes önképzés és az otthoni ismerősök, barátok segítsége. Megállapítható, hogy a férfiak nyitottabbak voltak ezen elsajátítási lehetősé- 
gek iránt és gyakrabban használták ezeket, mint a nők. A generációk az iskolai keretek között megvalósuló formális és a nem formális módszerekben különböztek egymástól. A munkaerőpiaci státusz alapján a közvetlen hozzátartozó által történő oktatásban voltak szignifikánsan különbözőek az eredmények, ezt gyakrabban alkalmazták a vezetők, mint a beosztottak.

Korrelációs vizsgálattal azt is elemeztük, hogy ezek a módok mennyire sikeresek. $\mathrm{A} z$ iskolai és az önképzés, valamint az iskolai formális keretek esetében erős pozitív, szignifikáns korreláció volt kimutatható, a digitális tudást jelző főkomponens értékével: $r=0,459$, illetve $r=0,343$. A közvetlen hozzátartozó által történő oktatás és a digitális jártasság között nem volt igazolható szignifikáns összefüggés, azaz ez a mód nem tűnik sikeres metódusnak. Ugyanakkor a fókomponenst alkotó egyik változó, a digitális újdonságokkal szembeni előítélet igen erősen korrelált azzal, hogy a közvetlen hozzátartozónk avagy a barátaink segítségével sajátítjuk el a digitális tudást: $r=0,286$ és $r=0,305$. Ezek az eredmények azt támasztják alá, hogy digitális kérdésekben erőteljesebben támaszkodunk a családon, a baráti-ismertségi körön kívüli segítségre.

Végezetül fontosnak tartottuk azt is feltárni, hogy milyen digitális eszközöket és milyen gyakran használnak a válaszadók otthon és a munkahelyükön. A gyakoriságot az egyes eszközök esetében ötfokozatú skálán - ahol az 1-es az egyáltalán nem, míg az 5-ös az igen gyakran választ jelentette - kellett a részvevőknek megadniuk. Otthon leggyakrabban az okos telefont, a laptopot és asztali számítógépet használják a válaszadók, míg a munkahelyen az okos telefont, az asztali számítógépet és a laptopot veszik igénybe.

6. táblázat: Eszközök gyakorisági használata otthon és a munkahelyen

(ötfokozú skála átlaga, szórása)

\begin{tabular}{lcccccc}
\hline \multirow{2}{*}{ Eszközök } & \multicolumn{2}{c}{ Otthon } & & \multicolumn{2}{c}{ Munkahelyen } \\
\cline { 2 - 3 } \cline { 6 - 7 } & Átlag & Szórás & & Átlag & Szórás \\
\hline Okos-mobiltelefon & 4,57 & & 0,842 & & 3,84 & 1,352 \\
Hordozható számítógép (laptop) & 3,62 & 1,306 & & 3,28 & 1,594 \\
Aszztali számítógép & 3,07 & 1,591 & & 3,49 & 1,672 \\
Felhőalapú technológia & 3,05 & 1,465 & & 2,90 & 1,575 \\
Tablet & 2,46 & 1,483 & & 1,94 & 1,345 \\
Okosóra & 2,14 & 1,561 & & 1,83 & 1,370 \\
Hagyományos mobiltelefon & 1,72 & & 1,256 & & 1,90 & 1,446 \\
\hline
\end{tabular}

Forrás: Saját szerkesztés

Az ANOVA elemzés alapján a nem, kor és munkaerőpiaci státusz szerint is szignifikáns különbség mutatható ki az otthoni és a munkahelyi eszközhasználatban. Nemek szerint az otthoni használat esetében az asztali gép, a tablet, a hagyományos mobiltelefon, az okosóra, a felhőalapú technológia, míg a munkahelyi alkalmazás kapcsán a hordozható számítógép, a tablet, a hagyományos mobiltelefon, az okosóra és a felhőalapú technológia használatában tapasztalható eltérés a férfiak javára. A generációk esetében az otthoni asztali számítógépek használatában volt szignifikáns eltérés (az idősebb baby boom - generáció részesítette előnyben), míg a felhőalapú technológiát szignifikán- 
san többször használják a munkahelyükön a $Z$ generáció tagjai, mint a többi generáció. A munkaerőpiaci státusz alapján az okosóra, a felhő alapú technológia, illetve a tablet használatát inkább a vezetők választották otthon, míg a munkahelyi használatot nézve csak az asztali számítógép igénybevételének gyakoriságában nem különböztek a vezetők és a beosztottak.

A korrelációs elemzés azt mutatta, hogy a digitális tudás - melyet a korábbiakban kialakított fókomponenssel mértünk - pozitív irányú korrelációban van a munkahelyi laptop $(r=0,271)$, az okosóra $(r=0,177)$ és a felhőalapú technológia működtetésével $(r=0,399)$.

\section{Konklúzió}

A tanulmány egy 2019. évi kutatás eredményeit foglalta össze, amely a felsőfokú végzettségűek digitális kompetenciáját vizsgálta. A szerzők által megfogalmazott hipotézis az adott eredmények tükrében a vizsgálati mintára igazolódott, azaz a résztvevők digitális kompetenciája erős, és ezt használják otthon és a munkahelyükön is.

$\mathrm{A} z$ eredmények azt is igazolták, hogy jellemzőbb a munkahelyi használat, mint az otthoni. A válaszadók számos eszközt használnak otthon és a munkahelyükön, ezek alkalmazásában lényeges különbséget nem lehetett kimutatni. A mintában szereplők alapvetően pozitívan álltak a digitális innováció vívmányaihoz. Ugyanakkor azt is jól lehetett látni a vizsgálat során, hogy számos lehetőséget kínál ez a tudás, megkönnyítve és kényelmessé téve az egyén munkahelyi és otthoni életét. A digitális tudás elsajátításának számos módszere van, hozzátéve, hogy a megkérdezettek alapvetően a formális jellegü módszerekben látták az ismeretek megszerzésének lehetséges útját.

Egyre több munkahely igényli az alkalmazottak IKT-tudását, digitális készségeit a munkavégzés különböző fázisaiban. Az Európai Bizottság egyik felmérése szerint a munkahelyek 90\%-ának legalább az alapvető számítógépes ismeretekre van szüksége (European Commission 2014). A digitális kompetenciát folyamatosan fejleszteni kell olyan változó eszközökkel és gyakorlatokkal, amelyeket az emberek a munkájukban, a tanulmányaikban és a szabadidejükben használnak. Az alapvető eszközök és a számítógépes alkalmazások elsajátítása csak az első lépés a fejlett ismeretek, a készségek és az attitűdök felé. A digitalizáció növekedése a digitális készségek iránti kereslet növekedéséhez vezet, ami várhatóan tovább folytatódik. Kérdés, hogy az Unió tagországai mennyire vannak felkészülve a megnövekedett igény teljesítésére.

\section{IRODALOM}

Carretero, S., Vuorikari, R. \& Punie, Y. (2017) DigComp 2.1: Állampolgári digitáliskompetenciakeret nyolc jártassági szinttel és gyakorlati példákkal. European Commission's Joint Research Centre, European Union. https://pmk.hu/wp-content/ uploads/2019/07/DigComp2.1_forditas_6_20200130.pdf [Letöltve: 2019. 10. 20.]

Európai BizotTság (2019) A digitális gazdaság és társadalom fejlettségét mérö mutató (DESI) 2019, országjelentés Magyarország. https://ec.europa.eu/newsroom/dae/document. cfm?doc_id=59993 [Letöltve: 2019. 10. 20.] 
European Commission (2014) Measuring Digital Skills Across the EU: EU Wide Indicators of Digital Competence. https://ec.europa.eu/digital-single-market/en/news/measuringdigital-skills-across-eu-eu-wide-indicators-digital-competence [Letöltve: 2019. 10. 20.]

NAT (2012) A Kormány 110/2012. (VI. 4.) Korm. rendelete a Nemzeti alaptanterv kiadásáról, bevezetéséről és alkalmazásáról. Magyar Közlöny, 2012. évi 66. szám. https://ofi. oh.gov.hu/sites/default/files/attachments/mk_nat_20121.pdf [Letöltve: 2019. 10. 20.]

Székely L. \& Aczél P. (2018) Magyar világ 2.0 - fiatalok és az újmédia. In: Székely L. (ed.) Magyar fiatalok a Kárpát-medencében - Magyar Ifjúság Kutatás 2016. Budapest, Kutatópont Kft. - Enigma 2001 Kiadó és Médiaszolgáltató Kft.

TARI A. (2010) Y generáció alapján. Budapest, Jaffa Kiadó.

A cikk a Creative Commons Attribution 4.0 International License (https://creativecommons.org/licenses/ by/4.0/) feltételei szerint publikált Open Access közlemény, melynek szellemében a cikk bármilyen médiumban szabadon felhasználható, megosztható és újraközölhető, feltéve, hogy az eredeti szerző és a közlés helye, illetve a CC License linkje és az esetlegesen végrehajtott módosítások feltüntetésre kerülnek. (SID_1) 